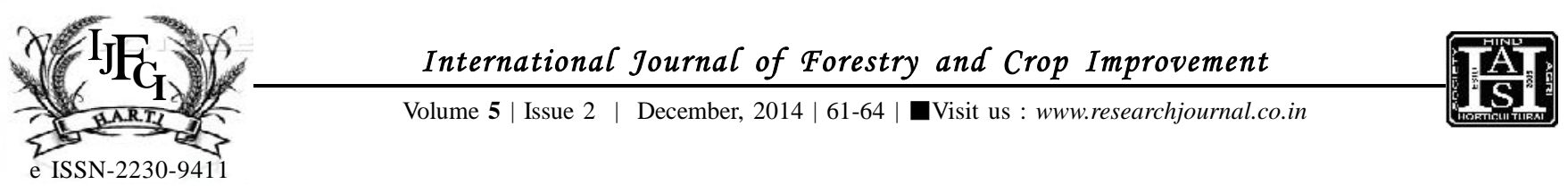

\title{
Eefect of urea and zinc treatments on biochemical components of guava fruits cv. BHAVNAGAR RED
}

\author{
J.M. PARMAR, K.M. KARETHA AND P. J. RATHOD
}

\begin{abstract}
A field experiment was conducted during 2012-2013 to study the effect of foliar application of Zn and Urea on guava fruits to see the biochemical changes in guava fruits and found that the TSS, was significantly increased $\left(11.85^{\circ} \mathrm{Brix}\right)$ with treatment $\mathrm{U}_{2}(1.5 \%$ urea). Acidity was significantly affected by $\mathrm{Zn}$ and urea treatments. It was noted that foliar spray of urea decreased the acidity. The minimum acidity of 0.48 per cent was observed where 1.5 per cent urea was sprayed. The ascorbic acid was significantly increased $(220.79 \mathrm{mg} / 100 \mathrm{ml})$ and the pectin content was also significantly affected by various levels of urea. Significantly the highest pectin content $(0.67 \%)$ was observed with treatment $U_{2}(1.5 \%$ urea). The reducing sugar was significantly increased with urea @ $1.5 \%$ and same treatments recorded significantly the maximum non-reducing sugar $(4.66 \%)$. The total sugar was significantly increased $(7.03 \%)$ with treatment $\mathrm{U}_{2}(1.5 \%$ urea). Over all result showed that foliar spray of urea and zinc sulfate can altered the biochemical parameters such as TSS, acidity, reducing sugar, pectin content, ascorbic acid, non-reducing sugar and total sugar in guava fruits.
\end{abstract}

KEY WORDS : Urea, Zinc tretements, Biochemical components, Guava fruits

How to cite this Article : Parmar, J.M., Karetha, K.M. and Rathod, P.J. (2014). Eefect of urea and zinc treatments on biochemical components of guava fruits cv. BHAVNAGAR RED. Internat. J. Forestry \& Crop Improv., 5 (2) : 61-64.

Article Chronical : Received : 19.10.2014; Revised : 30.10.2014; Accepted : 16.11.2014

\section{MEMBERS OF RESEARCH FORUM}

Address of the Correspondence :

J.M. PARMAR, Department of Horticulture, College of Agriculture, Junagadh Agricultural University, JUNAGADH (GUJARAT) INDIA

Address of the Coopted Authors :

K.M. KARETHA AND P.J. RATHOD, Department of Processing and Food Engineering, College of Agricultural Engineering and Technology, Junagadh Agricultural University, Junagadh, JUNAGADH (GUJARAT) INDIA Email: kmkaretha@jau.in, pjrathod@jau.in 